\title{
Selective underground mining of complex structured ore bodies of Kryvyi Rih Iron Ore Basin
}

\author{
Vsevolod Kalinichenko ${ }^{1}$, Serhii Pysmennyi ${ }^{1 *}$, Nataliia Shvaher ${ }^{2}$, and Olena Kalinichenko ${ }^{1}$ \\ ${ }^{1}$ Kryvyi Rih National University, Department of Underground Mining of Mineral Deposit, \\ 11 Matusevycha Ave., 50027 Kryvyi Rih, Ukraine \\ ${ }^{2}$ Kryvyi Rih National University, Department of Labor and Law, 11 Matusevycha Ave., 50027 \\ Kryvyi Rih, Ukraine
}

\begin{abstract}
Selective mining of complex structured ore bodies will enable increased iron content in the mined ore mass in underground mining at Kryvyi Rih iron ore basin applying the existing mining systems. The article determines the way the grade changes in a mine block of a complex structured ore body when applying bulk and selective mining as well as factors influencing indices of extracting ore mass from the block. The investigation results prove that it is reasonable to mine complex structured ore deposits with barren inclusions applying selective mining if the iron content in the block varies from 64 to $67 \%$ and horizontal thickness of the barren inclusion makes $4-12 \mathrm{~m}$. At that, the thickness ratio should not exceed 0.3. Stoping methods should be applied to receive high indices of ore mass extraction. There is determined an ore/barren inclusion-to-ore body thickness ratio considering the dilution factor that confirms practicability of selective mining of complex structured ore bodies. Selective mining of complex structured ore deposits of Kryvyi Rih iron ore basin applying open stoping enables increasing the mined ore mass quality without considerable capital and operating costs and, consequently, staying on the market and enhancing the environmental situation in the region.
\end{abstract}

\section{Introduction}

Ore deposits of Kryvyi Rih iron ore basin are represented by single and parallel-contiguous bodies consisted of complex structured ore bodies. The number of the areas within the deposits makes about $8 \%$ on average, i.e. over $100 \mathrm{mln} t$ of the balance rich iron ore reserves of Kryvyi Rih iron ore basin. The horizontal thickness of barren/ore inclusions (BOI) varies from 5 to $12 \mathrm{~m}$ with the Protodiakonov hardness ratio of $8-16$ points which is average $4-6$ points higher than that of the main ore massif.

When mining deposits represented by complex structured ore bodies (CSOB) by traditional underground methods, the iron content in the mined ore mass decreases by $3-6 \%$ in relation to the main grade with ore losses being 1.5-2.0 times larger as compared with the standard. This results in decreased iron content in the mined ore mass and loss of the global

\footnotetext{
*Corresponding author: psvknu@gmail.com
} 
market. Selective mining of the mineral from blocks enables mining it with the iron content in the ore mass of over $62 \%$ and thus holding market positions.

Mining of complex structured ore bodies is treated in a number of works dealing with determining regularities of mining indices, rock pressure manifestations, mining sequence and determining parameters of main structural elements of mining systems [ $1-5]$. To settle resource saving issues, a complex approach to building the concept of managing environmental and economic systems should be applied considering functional elements and using principles of organizational and technical management [6-9].

Efficiency of mining deposit reserves are influenced by mining and geological conditions. The main factors of successful mining CSOB include: stoping sequence, rock pressure, work intensity, number and stability of pillars, level height, location of stopes and pillars in ore bodies of the main strike.

When dealing with the efficiency of underground mining at the Kiruna mine (Sweden), it was proposed to grade the ore mass according to iron content under the ground. For this purpose, the required number of opening main openings were built. Later on the company had to deal with the problem of mining objects' stability [10, 11]. Currently, there are developed techniques of controlling the state of the ore massif disturbed by underground mining operations [12-14]. However, due to technological peculiarities of underground mining of Kryvyi Rih iron ore deposits implementation of the techniques will cause escalation in mining costs and decrease of annual productivity.

Practice of Kryvbas underground mines proves that efficiency of mining complex structured deposits is influenced by stoping sequence, thickness and strength of the interbedded layer (barren inclusion), mining systems $[2,15,16]$. When mining CSOB by room and pillar methods, the number of pillars should be minimal as they are stress concentrators and complicate conditions of further mining. Determining shear and destressed zones in mining parallel bodies has proved that intensity of rock pressure in enclosing rocks of the hanging wall is lower than that in underlying rocks of the footwall [17-19].

The opposite conclusion is made in [20 - 21], i.e. advance mining from the side of the hanging wall reduces rock pressure in main strike layers. Such controversial conclusions are caused by the fact that the above investigations were conducted under different conditions and at different depths. In [12] various zones of rock pressure changes were studied that is conditioned by advance mining of one of the layers, temporary delays in works and their spatial relationship. It is determined that inclined ore bodies cross impact decreases when their dips increase.

The results of investigating optimization of ore raw materials mining and treatment enable the conclusion that efficiency indices of controlling concentration of ore raw materials significantly depend on accuracy of process parameters [22]. In most cases when developing methods of non-destructive control of ore material characteristics, electromagnetic, ultrasonic and radiometric methods are applied.

The authors of [23-26] consider it reasonable to use stoping for mining ore bodies of the main strike and bulk caving for the parallel strike. The current flowsheets and standards are developed for mining CSOB with the horizontal thickness of the barren inclusion of $35 \mathrm{~m}$ and more, ores and rocks should be strong and stable. However, what minimal thickness should be mined by the selective method still remains understudied.

\section{Methods}

To solve the problem of escalating the iron content and reducing ore losses in mining deposits with complex structured ore bodies, it is expedient to apply the approach proposed in $[27,28]$. The authors suggest modernization of traditional concentrating processes 
through introducing hydrometallurgical and chemical treatment which enhances concentration efficiency due to use of other kinds of energy. Such modernization of concentrating is based on force impacts on a substance during disintegration in the activator and does not consider processes of underground mining.

The critical analysis of issues of development and processing of useful minerals enables the following conclusions.

1. Most researchers propose to increase the iron content in the mined ore mass through application of an underground or surface concentrating complex that will inevitably increase mining costs and result in loss of the world market.

2. To increase the iron content in the mined ore mass at the first stage through application of the resource saving selective mining in order to exclude the concentrating process. At that, traditional methods involving concentration combines are suggested for mining ore bodies with the horizontal thickness of barren/ore inclusions of less than $12 \mathrm{~m}$.

Thus, when mining CSOB, there occurs a necessity of enhancing the resource saving technology to provide escalation of the iron content at selective mining of deposits depending on mining systems applied. So, it is essential to determine how barren inclusion thickness influences indices of ore mass extraction.

\section{Results and discussion}

According to the suggested classification, efficiency of this or that applied mining system in underground mining of iron ore deposits consists of the following: indices of ore extraction from a block containing BOI; the grade of the mined rock mass; mining costs [29].

The world market requires saleable products with the grade of the mined ore mass of not less than $62 \%$. The European market offers considerably lower prices for saleable products with the iron content of less than $62 \%$, otherwise they are not competitive at all.

The permissible weight dilution of ore when mining a complex structured ore body by the bulk mining method is determined according to the formula:

$$
D=\frac{\sum F e_{p . i}-F e_{\min }}{\sum F e_{p . i}-\sum F e_{B O I . i}},
$$

where $D$ is the permissible dilution , unit fractions; $F e_{p . i}$ is the grade in a block mined, \%; $F e_{\text {min }}$ is the minimum permissible grade in the ultimate dose of the drawn ore mass, \%; $F e_{B O I . i}$ is the grade in BOI, $\%$.

Dependencies of the permissible dilution variations in the caved ore according to (1) when mining CSOB of rich ores by open stopes; mass induced caving of BOI and ore and backfilling are presented in Fig. 1.

Fig. 1 demonstrates that decrease of the grade in the mined ore mass with the standard dilution from 63 to $62 \%$ (by 1\%) is not possible for the considered mining methods applied in underground mines as the permissible dilution is significantly lower.

When applying mining systems with backfilling dead areas, dilution of ore makes average 5\%; the permissible weight dilution when mining CSOB varies from 1.5 to $3.7 \%$ and the iron content in BOI grows from 0 to $40 \%$. In case of the iron content in the ore massif of 64 or $65 \%$, the iron content in BOI should make 27 and $7 \%$ respectively at the standard dilution of the mined ore mass.

When mining CSOB by open stoping systems, the mined ore mass with the content of $62 \%$ at the ore content in the ore massif of lower than $64 \%$ cannot be obtained as the standard dilution makes $9 \%$ on average. The required grade $(62 \%)$ in the mined ore mass with the iron content in the ore massif of 65,66 and $67 \%$ can be obtained when the iron quality in BOI makes more than 34, 23 and $12 \%$ respectively. 


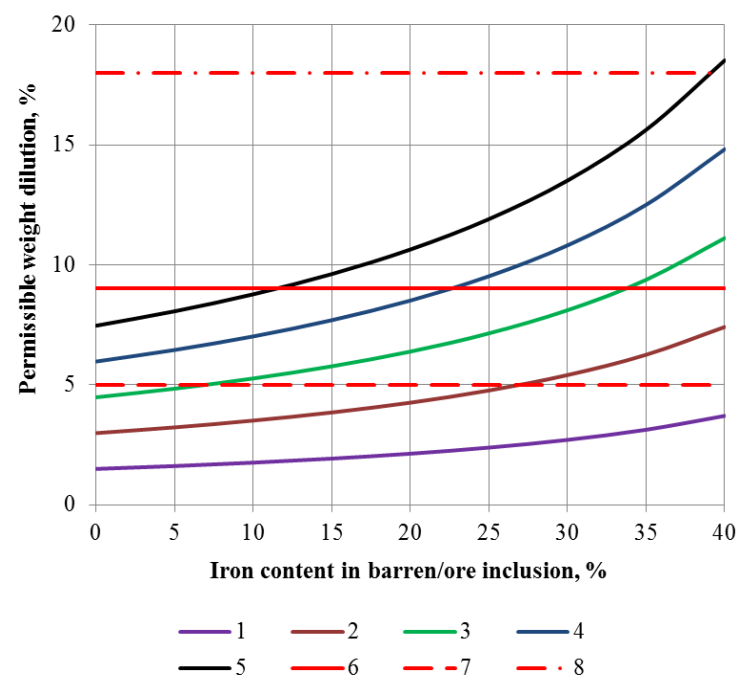

Fig. 1. Dependencies of the permissible dilution in the ultimate dose of the drawn ore mass on the iron content in BOI and the rock massif when mining rich ores with the grade of $67 \%: 1,2,3,4,5-$ the iron content in the rock massif of $67,66,65,64$ and $63 \%$ respectively; $6,7,8$ - standard dilution of the mined mineral when applying open stoping, mass induced caving of BOI and ore and backfilling respectively.

Thus, application of mass caving in mining complex structured ore bodies is limited significantly. To secure the grade in the mined ore mass at the level of $62 \%$, the iron content in BOI and ore massif must be greater than 40 and $67 \%$ respectively. The system with backfilling the dead area is one of the most efficient when mining CSOB as it allows the ore mass with iron content of $62 \%$ regardless the iron content in BOI at bulk mining.

It should be noted that the obtained indices only reflect quantitative characteristics as the ore-to-BOI volume ratio is not considered.

In mining complex structured ore bodies the basic condition of mining a block is the average iron content in the mined ore mass. In bulk mining of CSOB the average iron content in a mine block is determined according to the formula:

$$
F e_{a v}=\frac{\sum\left(F e_{p . i} \cdot Q_{p . i}\right)+\sum\left(F e_{B O I . i} \cdot Q_{B O I}\right)}{Q_{b}},
$$

where $F e_{a v}$ is the average useful component content in a mine block, \%; $Q_{p . i}$ is the ore reserve in a block with the iron content of over $62 \%$, kt; $Q_{B O I . i}$ is the ore reserve in BOI located within the mine block, kt; $Q_{b}$ is the reserve of the block, kt.

In general, the ore reserve in a block or BOI is determined by the formula:

$$
Q_{b}=L \cdot h \cdot M \cdot \gamma,
$$

where $Q_{b}$ is the ore reserve, $\mathrm{t} ; L$ is the block length along the strike, $\mathrm{m} ; h$ is the height of a block level (sub-level), $\mathrm{m} ; M$ is horizontal thickness of the ore body, $\mathrm{m} ; \gamma$ is the specific weight, $\mathrm{t} / \mathrm{m}^{3}$.

When analyzing (3) which is part of (2), it should be noted that the block length along the strike and the height of its level (sub-level) are constant values. So, after conversion the average iron ore content in the block at bulk mining looks like: 


$$
F e_{a v}=\frac{\sum F e_{p . i} \cdot m_{p . i} \cdot \gamma_{p}+\sum F e_{B O I . i} \cdot m_{B O I} \cdot \gamma_{B O I}}{\sum m_{p . i} \cdot \gamma_{p}+\sum m_{B O I} \cdot \gamma_{B O I}},
$$

where $m_{p . i}$ is the horizontal thickness of ore bodies in a mine block, $\mathrm{m} ; m_{B O I}$ is the horizontal thickness of BOI, $\mathrm{m} ; \gamma_{o}, \gamma_{B O I}$ is the specific weight in the ore body and the barren/ore inclusion respectively, $\mathrm{t} / \mathrm{m}^{3}$.

Let us analyze the impact of the block or BOI thickness on the average iron content in a mine block when the iron content in ore and in BOI makes 67 and 30\% respectively. The results of calculating the average ore content in a mine block of CSOB according to (4) are given in Fig. 2.

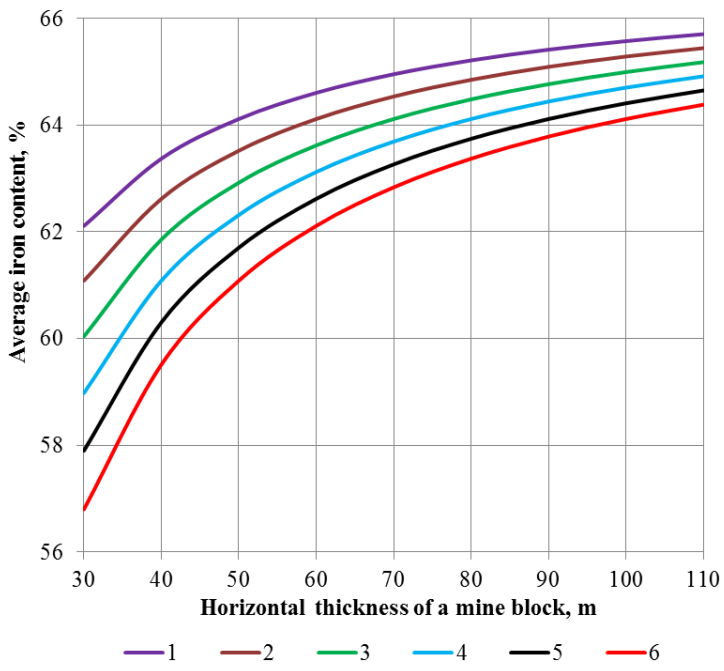

Fig. 2. Dependencies of the average iron content in the ore mass of CSOB on the horizontal thickness of a mine block and thickness of BOI at bulk mining of a block: 1, 2, 3, 4, 5, 6 - horizontal thickness of $\mathrm{BOI}$ of 5, 6, 7, 8, 9 and $10 \mathrm{~m}$ respectively.

Fig. 3 shows that the average iron content in a block is significant impacted by the horizontal thickness of BOI. Increase of BOI thickness from 5 to $10 \mathrm{~m}$ and the iron content in ore of $67 \%$ and that in BOI of $30 \%$ decreases the average content from 62 to $57 \%$ at the block thickness of $30 \mathrm{~m}$ and from 65.5 to $64.5 \%$ at the block thickness of $110 \mathrm{~m}$.

It should be noted that (4) is true when the block is mined by traditional methods with bulk mining without considering the mining system. The iron content in the ore mass considering indices of ore extraction when mining a block by the corresponding mining system is determined by the formula:

$$
F e_{m o m}=F e_{a v}-\frac{\left(F e_{a v}-F e_{\text {rock }}\right) \cdot D}{100},
$$

where $F e_{\text {mom }}$ is the useful component content in the mined ore mass, $\% ; F e_{\text {rock }}$ is the grade in enclosing rocks of the footwall and the hanging wall, $\% ; D$ is dilution of the mined ore mass at mining the block by the corresponding system, $\%$.

Fig. 3 presents dependencies of the varying iron content in the mined ore mass at the iron content in: ore - of $65 \%$, BOI - of $30 \%$, enclosing rocks - of $32 \%$ and BOI horizontal thickness of $8 \mathrm{~m}$.

Fig. 3 demonstrates that increase of the mine block horizontal thickness from 30 to 
$110 \mathrm{~m}$ and constant BOI thickness of $8 \mathrm{~m}$ raises the average quality of the ore mass in the block from 57 to $63 \%$ (curve 7 ). It should be noted that to provide the iron quality of $62 \%$ in the massif, CSOB thickness must be $75 \mathrm{~m}$ and more. Iron ores are mined by various systems with certain ore dilution indices at ore drawing. Fig. 4 (curves 1, 2, 3) shows that to provide the iron quality at the level of $62 \%$ is not possible due to high dilution indices.

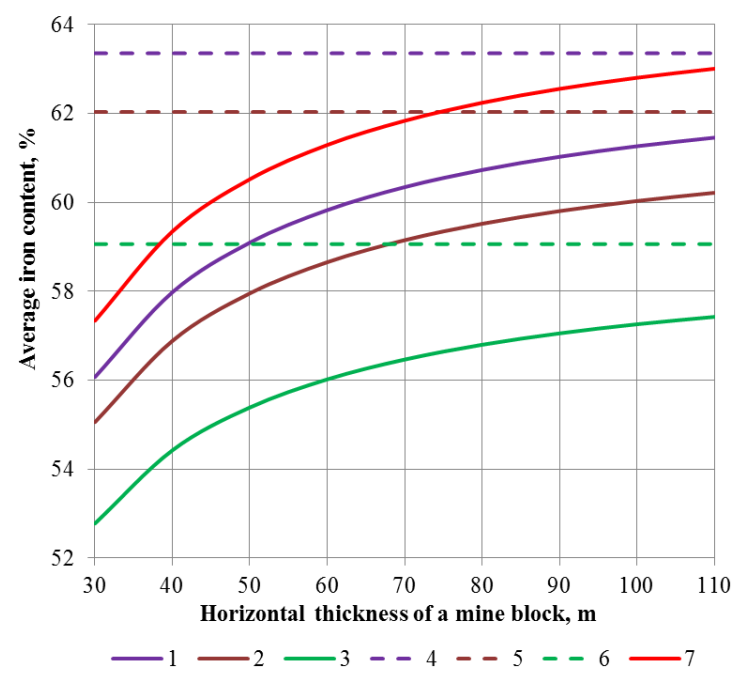

Fig. 3. Dependencies of the average iron content on the horizontal thickness of a mine block at BOI thickness of $8 \mathrm{~m}: 1,2,3$ - dilution of the ore mass of 5,9 and $18 \%$ respectively at bulk mining of a block; 4, 5, 6- dilution of the ore mass of 5, 9 and $18 \%$ respectively at selective mining of a block; 7 - average iron content in a mine block at bulk mining.

At bulk mining by mass caving, the thickness increase from 30 to 110 m reduces the quality of iron in the rock mass from $59-63 \%$ to $53-57 \%$. Thus, the required quality of iron in the mined mass can be obtained through selective mining of a mine block. Fig. 3 (curves 4,5 ) shows that application of stoping systems raises iron grade in the mined ore mass up to $62 \%$.

The mass caving system cannot provide the level of the required quality of iron in the mined rock mass at $62 \%$ due to high dilution of the ore of $18 \%$ (Fig. 3, curve 6).

The maximal permissive thickness of BOI considering the horizontal thickness of a mine block, the mineral grade in the ore massif and the average quality in a block is determined by the expression:

$$
\left[m_{B O I}\right]=\frac{\sum\left(F e_{p . i} \cdot m_{p . i}\right) \cdot \gamma_{p}-\sum\left(F e_{\min } \cdot m_{p . i}\right) \cdot \gamma_{p}}{\left(F e_{\min }-F e_{B O I . i}\right) \cdot \gamma_{B O I}} \rightarrow \max ,
$$

where $\left[m_{B O I}\right]$ is the critical thickness of BOI, \%.

Fig. 4 presents dependencies of the critical thickness of BOI at bulk mining of rich or lean ores on the horizontal thickness of a mine, the content of iron in ore, BOI and the mined ore for rich ores of $62 \%$ and for lean ores of $26 \%$.

The dependencies in Fig. 4 show that with the increase of the content of iron in BOI to $40 \%$, its the critical thickness rises from 1.8 to $12.0 \mathrm{~m}$ at mining rich ores. When the horizontal thickness of a mine block rises from 30 to $80 \mathrm{~m}$, it is reasonable to apply selective mining if the BOI thickness does not exceed $2-8 \mathrm{~m}$ with the iron content in the barren/ore inclusion of $20 \%$. 


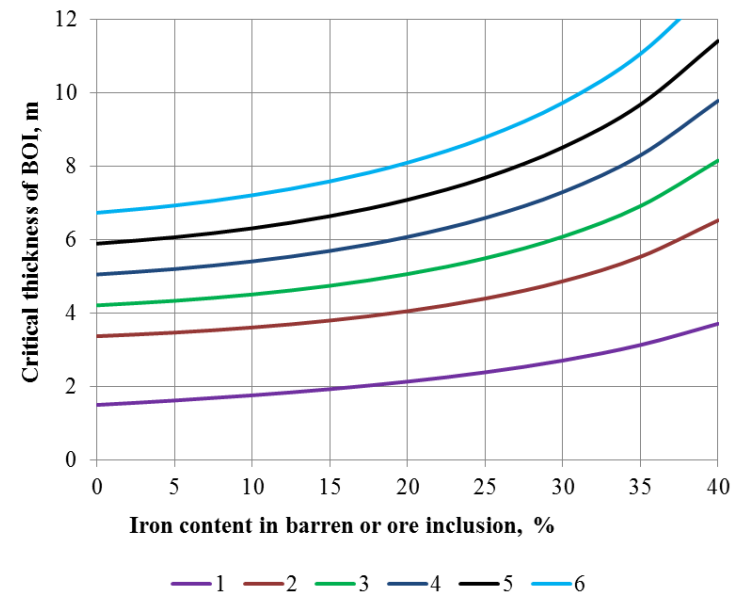

Fig. 4. Dependency of the critical thickness of BOI on the iron content at bulk mining of a mine block (with the content of ore in the ore massif of $65 \%$, in the mined ore mass of $62 \%$ ) and on horizontal thickness of the ore body: 1, 2, 3, 4, 5, 6- horizontal thickness of a mine block represented by CSOB of $30,40,50,60,70,80 \mathrm{~m}$ respectively.

However, (6) does not consider BOI horizontal thickness and dependency of indices of working out a block by a mining system. So, the critical thickness of BOI at bulk mining of a block considering its horizontal thickness, the grade and the dilution ratio is determined as follows:

$$
\left\{\begin{array}{l}
{\left[m_{B O I}\right]=\frac{\sum\left(F e_{p . i} \cdot m_{p . i}\right) \cdot \gamma_{p}-\sum\left(F e_{\min } \cdot m_{p . i}\right) \cdot \gamma_{p}}{N_{B O I} \cdot\left(F e_{\min }-F e_{B O I . i}\right) \cdot \gamma_{B O I}} \cdot(1-D),} \\
m_{B O I} \leq\left[m_{B O I}\right],
\end{array}\right.
$$

where $\left[m_{B O I}\right]$ is the critical thickness of BOI which provides the corresponding extraction indices, $\mathrm{m}$.

Thus, it has been determined that the width of BOI and a mine block directly influences the content of iron in the mined ore mass.

Analysis of (4) demonstrates that besides a block thickness and minable width and the miningextracting ore from a block at mining CSOB is determined according to the formula:

$$
K_{\text {ext }}=\frac{\sum M_{p . i}}{M_{b}} \cdot \frac{1-B}{1-3}=\left(1-K_{m . B O I}\right) \cdot \frac{1-B}{1-D},
$$

where $K_{\text {ext }}$ is the ore extraction ratio, unit fractions; $K_{m . B O I}$ is the barren/ore inclusion-toblock thickness ratio, unit fractions.

Fig. 5 presents the dependencies of the thickness ratio on BOI width, Fig. 6 shows the same on the thickness of a block at bulk mining.

Fig. 5 demonstrates that increase of the block thickness from 40 to $80 \mathrm{~m}$ decreases the thickness ratio from 0.30 to 0.06 ; increase of the barren/ore inclusion thickness from 5 to $12 \mathrm{~m}$ escalates the thickness ratio from 0.06 to 0.30 .

Equating the BOI-block thickness ratio to the average mined ore-to-ore body iron content ratio enables obtaining the basic condition (9) in which selective mining of CSOB is practicable: 


$$
K_{m . B O I} \geq \frac{F e_{o m}}{F e_{o b}} \cdot(1-D),
$$

where $\mathrm{Fe}_{\text {om }}$ is the average content of iron in the mined ore at bulk stoping and BOI from the block, $\% ; F e_{o b}$ is the average content of iron in ore bodies around BOI in the block, $\%$.

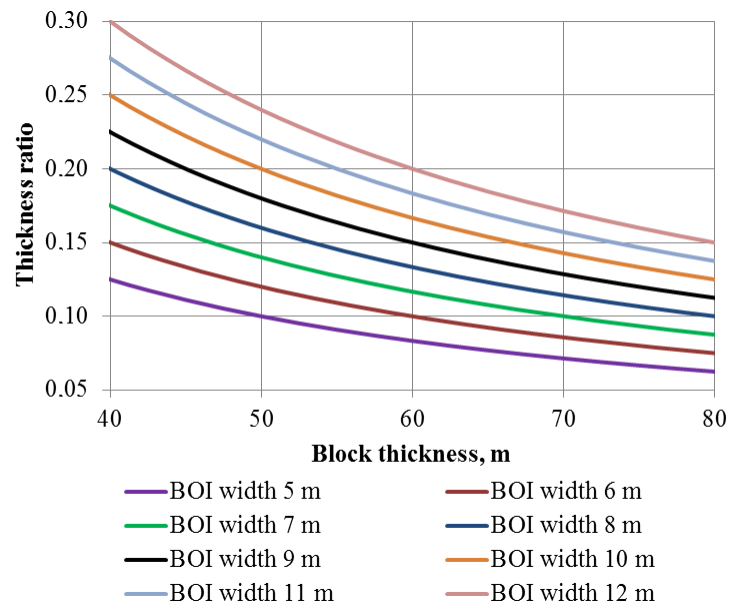

Fig. 5. Dependency of the thickness ratio on the width of the barren/ore inclusion.

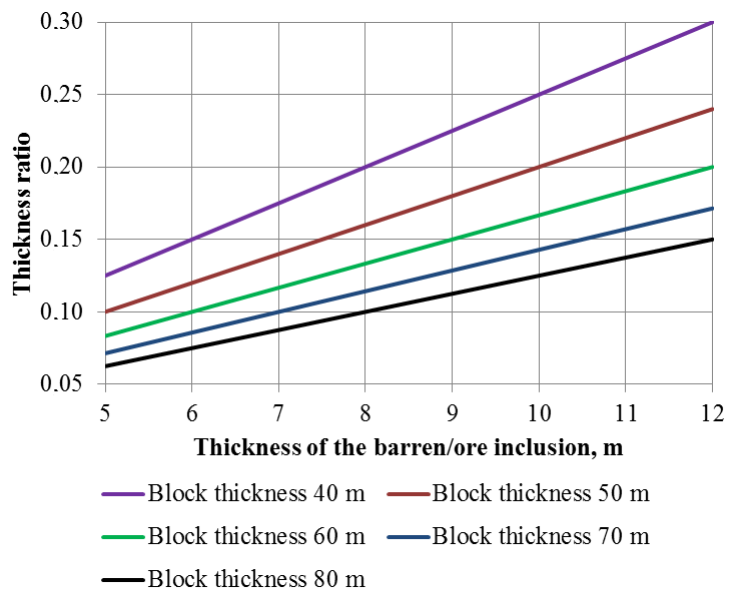

Fig. 6. Dependency of the thickness ratio on the block thickness.

\section{Conclusions}

The investigations conducted results in the conclusion that selective mining of complex structures ore bodies enable increase of the content of iron in the mined ore mass. However, high extraction indices can be reached by applying certain mining systems in current mining and geological conditions. It is practicable to mine ore bodies containing barren inclusions of 4 to $12 \mathrm{~m}$ by systems that are applied at Kryvbas underground mines.

Thus, selective mining applied at blocks represented by CSOB will enable enhancing mined ore mass indices, keeping the position on the world market and decreasing mining and processing costs. 
This work was conducted within the project "Determination of regularities of the stress-strain state of rocks disturbed by workings with the purpose of developing resource-saving ore mining technologies" (State registration No. 0115U003179).

\section{References}

1. Fedko, M.B., Kolosov, V.A., Pismennyi, S.V., \& Kalinichenko, Ye.V. (2014). Economic aspects of change-over to TNT-free explosives for the purposes of ore underground mining in Kryvyi Rih basin. Naukovyi Visnyk Natsionalnoho Hirnychoho Universytetu, (4), 79-84.

2. Shchelkanov, V.A., Khivrenko, O.Ya., \& Khivrenko, V.O. (2001). Analiz slozhnostrukturnykh zalezhey Krivbassa. Razrabotka rudnykh mestorozhdeniy, (75), 30-35.

3. Pysmennyi, S.V. (2017). Metodyka vyznachennia aktyvnoi zony sklepoutvorennia na konturi pidzemno-transportnoi vyrobky pry kombinovanii rozrobtsi zalizorudnykh rodovyshch. Visnyk Natsionalnoho Tekhnichnoho Universytetu "Kharkivskyi Politekhnichnyi Instytut", 16(1238), 99106.

4. Stupnik, N., Kalinichenko,V., Kolosov, V., Pismennyi, S., \& Shepel, A. (2014). Modeling of stopes in soft ores during ore mining. Metallurgical and mining industry, (3), 32-36.

5. Lavrinenko, V.F., \& Lysak, V.I. (1991). Uroven' udaroopasnosti porod na glubokikh gorizontakh shakht Krivbassa. Razrabotka rudnykh mestorozhdeniy, (52), 30-37.

6. Morkun, V., \& Tron, V. (2014). Ore preparation energy-efficient automated control multi-criteria formation with considering of ecological and economic factors. Metallurgical and Mining Industry, (5), 8-10.

7. Morkun, V., Morkun, N., \& Pikilnyak, A. (2015). Adaptive control system of ore beneficiation process based on Kaczmarz projection algorithm. Metallurgical and Mining Industry, (2), 35-38.

8. Andreev, B.M., Brovko, D.V., \& Khvorost, V.V. (2015). Determination of reliability and justification of object parameters on the surface of mines taking into account change-over to the lighter enclosing structures. Metallurgical and mining industry, (12), 378-382.

9. Morkun, V., Morkun, N., \& Tron, V. (2015). Formalization and frequency analysis of robust control of ore beneficiation technological processes under parametric uncertainty. Metallurgical and Mining Industry, (5), 7-11.

10. Dineva, S., \& Boskovic, M. (2017). Evolution of seismicity at Kiruna Mine. Proceedings of the Eighth International Conference on Deep and High Stress Mining. Australian Centre for Geomechanics, 125-139. https://papers.acg.uwa.edu.au/p/1704 07 Dineva/

11. Biruk, Y., \& Mwagalanyi, Hannington. (2010). Investigation of Rock-fall and Support Damage Induced by Seismic Motion at Kiirunavaara Mine. Department of Civil, Environmental and Natural Resources Engineering, 74. urn:nbn:se:Itu:diva-58466

12. Lutsenko, I., Fomovskaya, E., Koval, S., \& Serdiuk, O. (2017). Development of the method of quasioptimal robust control for periodic operational processes. Eastern-European Journal of Enterprise Technologies, 4, (2(88)), 52-60.

13. Lutsenko, I., Fomovskaya, O., Konokh, I., \& Oksanych, I. (2017). Development of a method for the accelerated two-stage search for an optimal control trajectory in periodical processes. EasternEuropean Journal of Enterprise Technologies, 3, (1(87)), 47-55.

14. Lutsenko, I., Tytiuk, V., Oksanych, I., \& Rozhnenko, Zh. (2017). Development of the method for determining optimal parameters of the process of displacement of technological objects. EasternEuropean Journal of Enterprise Technologies, 6, (3(90)), 41-48.

15. Khomenko, O., Sudakov, A., Malanchuk, Z., \& Malanchuk, Ye. (2017). Principles of rock pressure energy usage during underground mining of deposits. Naukovyi Visnyk Natsionalnoho Hirnychoho Universytetu, (2), 35-43.

16. Stupnik, N.I., Kalinichenko, V.A., Kolosov, V.A., Pismenniy, S.V., \& Fedko, M.B. (2014). Testing complex-structural magnetite quartzite deposits chamber system design theme. Metallurgical and mining industry, (2), 89-93. 
17. Vladyko, O., Kononenko, M., \& Khomenko, O. (2012). Imitating modeling stability of mine workings. Geomechanical Processes during Underground Mining: School of Underground Mining 2012, 147-150. https://doi.org/10.1201/b13157-26

18. Khomenko, O., \& Maltsev, D. (2013). Laboratory research of influence of face area dimensions on the state of uranium ore layers being broken. Naukovyi Visnyk Natsionalnoho Hirnychoho Universytetu, (2), 31-37.

19. Stupnik, N.I., Fedko, M.B. Pismenniy, S.V., \& Kolosov, V.A. (2014). Development of recommendations for choosing excavation support types and junctions for uranium mines of stateowned enterprise SkhidHZK. Naukovyi Visnyk Natsionalnoho Hirnychoho Universytetu, (5), 21-25.

20. Khomenko, O., Sudakov, A, Malanchuk, Z, \& Malanchuk, Ye. (2017). Principles of rock pressure energy usage during underground mining of deposits. Naukovyi Visnyk Natsionalnoho Hirnychoho Universytetu, (2), 35-43.

21. Carusone, O., \& Hudyma, M. (2017). Variations in apparent stress and energy index as indicators of stress and yielding around excavations. In Underground Mining Technology 2017 (pp. 205218). Canada: Australian Centre for Geomechanics.

22. Golik, V., Komashchenko, V., \& Morkun, V. (2015). Innovative technologies of metal extraction from the ore processing mill tailings and their integrated use. Metallurgical and Mining Industry, (3), 49-52.

23. Kononenko, M., \& Khomenko, O. (2010). Technology of support of workings near to extraction chambers. New Techniques and Technologies in Mining, 193-197. https://doi.org/10.1201/b11329$\underline{32}$

24. Tarasyutin, V.M. (2015). Geotechnology features of high quality martite ore from deep mines of Kryvyi Rih basin. Naukovyi Visnyk Natsionalnoho Hirnychoho Universytetu, (1), 54-60.

25. Khomenko, O. (2012). Implementation of energy method in study of zonal disintegration of rocks. Naukovyi Visnyk Natsionalnoho Hirnychoho Universytetu, (4), 44-54.

26. Khomenko, O., Kononenko, M., \& Myronova, I. (2013). Blasting works technology to decrease an emission of harmful matters into the mine atmosphere. Annual Scientific-Technical CollectionMining of Mineral Deposits, 231-235. https://doi.org/10.1201/b16354-43

27. Morkun, V., Gubin, G., Oliinyk, T., Lotous, V., Ravinskaia, V., Tron, V., Morkun, N., \& Oliinyk, M. (2017). High-energy ultrasound using to improve the quality of iron ore particles purification in the process of its enrichment. Eastern-European Journal of Enterprise Technologies, 6, (12(90)), 41-51.

28. Plevako, V., Potapov, V., Kycenko, V., Lebedynecj, I., \& Pedorych, I. (2016). Analytical study of the bending of isotropic plates, inhomogeneous in thickness. Eastern-European Journal of Enterprise Technologies, 4, (7(82)), 10-16.

29. Stupnik, N., Kalinichenko, V., \& Pismennyi, S. (2013). Pillars sizing at magnetite quartzites room-work. Annual Scientific-Technical Collection - Mining of Mineral Deposits, 11-15. http://dx.doi.org/10.1201/b16354-4 